\title{
Smart Polymers in Micro and Nano Sensory Devices
}

\author{
José Antonio Reglero Ruiz * (i), Ana María Sanjuán, Saúl Vallejos, Félix Clemente García \\ and José Miguel García
}

Departamento de Química Orgánica, Facultad de Ciencias, Universidad de Burgos, Plaza Misael Bañuelos s/n, 09001 Burgos, Spain; amsanjuan@ubu.es (A.M.S.); svallejos@ubu.es (S.V.); fegarcia@ubu.es (F.C.G.); jmiguel@ubu.es (J.M.G.)

* Correspondence: jareglero@ubu.es; Tel.: +34-947-258-085

Received: 25 February 2018; Accepted: 19 March 2018; Published: 21 March 2018

\begin{abstract}
The present review presents the most recent developments concerning the application of sensory polymers in the detection and quantification of different target species. We will firstly describe the main polymers that are being employed as sensory polymers, including, for example, conducting or acrylate-based polymers. In the second part of the review, we will briefly describe the different mechanisms of detection and the target species, such as metal cations and anions, explosives, and biological and biomedical substances. To conclude, we will describe the advancements in recent years concerning the fabrication of micro and nano sensory devices based on smart polymers, with a bibliographic revision of the research work published between 2005 and today, with special emphasis on research work presented since 2010. A final section exposing the perspectives and challenges of this interesting research line will end the present review article.
\end{abstract}

Keywords: sensors; smart polymers; detection; sensory devices

\section{Introduction}

Sensory or smart polymers present the ability to respond, reversibly or irreversibly, to different stimuli. Different sources can cause these responses: Temperature [1], electromagnetic pulses [2], biological molecules [3] or Ph media [4]. The smart polymer, when affected by these stimuli, changes various physicochemical properties, such as solubility, color, fluorescence, or even shape. The research devoted to the synthesis and analysis of the properties of these polymers has increased greatly in recent years, and they are starting to being used in a great variety of sectors, including biosensors [5], biomedical applications [6] and drug delivery [7].

The easy processability of the polymers makes them suitable for preparation in different shapes, such as coatings, films, fibers or wires, and with tuned hydrophilicity. The interaction between the sensor species or receptor motif and the guest in the smart polymer has led to the generation of different materials that are able to be used as sensory devices [8]. The analyte, or target species, produces a quantitative response in the sensory molecule, in terms of a noticeable physical property, which must be properly detected and quantified through recognition and transduction processes, thus producing an easily measurable macroscopic characteristic [9]. Our review work will be focused on chemical sensors based on smart polymers and will not consider physical sensors. Chemical sensors are devices that respond specifically to a particular analyte in an specific way through a chemical reaction, which is used to for the quantitative and/or qualitative determination of the analyte. On the other hand, physical sensors are concerned with measuring physical quantities such as length, weight, temperature, etc. for their own sake.

Although there are different characteristics that can be used to define the sensory behavior, selectivity and sensitivity are of primary significance. Sensitivity defines the detection limit or the 
minimal quantity of the analyte that can be detected, whereas selectivity is related to the capacity to detect a specific analyte in the presence of other target molecules (in a so-called interference analysis).

We have organized this review into three different sections. In the first part of the work, the descriptions of the different smart polymers that are used in sensory applications are detailed. In a second, we will present the mechanisms of detection and the main target species that are currently being immobilized and quantified using sensory polymeric materials, including the quickly evolving field of biological applications. Finally, we will describe the main sensory devices that employ sensory polymers that have been developed in the last 10-15 years, especially those focused on the micro- and nanoscale. The review will finalize with a brief summary and outlooks.

\section{Polymers with Sensory Properties}

A great variety of polymers can be used as sensory materials. In this review, we have selected the most important polymers that are currently being employed in sensory devices, as well as the polymers that are now undergoing extensive research and development as sensory materials. Thus, the sensory polymers analyzed include molecularly imprinted polymers, polymeric nanocomposites and hybrid polymers, acrylic polymers, polymers with chiral motifs, conjugated or conductive polymers and sensor arrays based on a set of polymers.

The preparation of molecularly imprinted polymers (MIPs) is carried out by the molecular imprinted technology, in which a polymer is combined in the polymerization process with the target species, which is used as template. Removing the target species creates precise hollow spaces that act as receptor sites for the target. The use of MIPs in different applications has been described previously by different authors [10]. Concerning polymeric nanocomposites and hybrid polymers, these two-phase structures are both formed by organic/inorganic phases, but in a different way. In the case of polymeric nanocomposites, the mixture starts from a polymeric moiety charged with inorganic particles with sizes in the nanometer range (1-100 nm). However, hybrid polymers are also formed of two different natures, but linked covalently, resulting in a single-phase structure [11].

Acrylic polymers belong to the "classical" polymeric materials, and have been analyzed for decades. These kinds of polymers can be used as sensory materials due to their versatility, and also a great variety of sensory units can be anchored chemically to their structure, thus conferring on them numerous advantages. The main acrylic polymers found in sensory applications are polymers prepared with esters of acrylic or methacrylic acid, acrylamide derivatives, and copolymers thereof, as shown in Scheme 1, in which different sensory units that can be precisely anchored to acrylic motifs to later prepare sensory polymers are presented. More examples can be found in the bibliography presented afterwards.
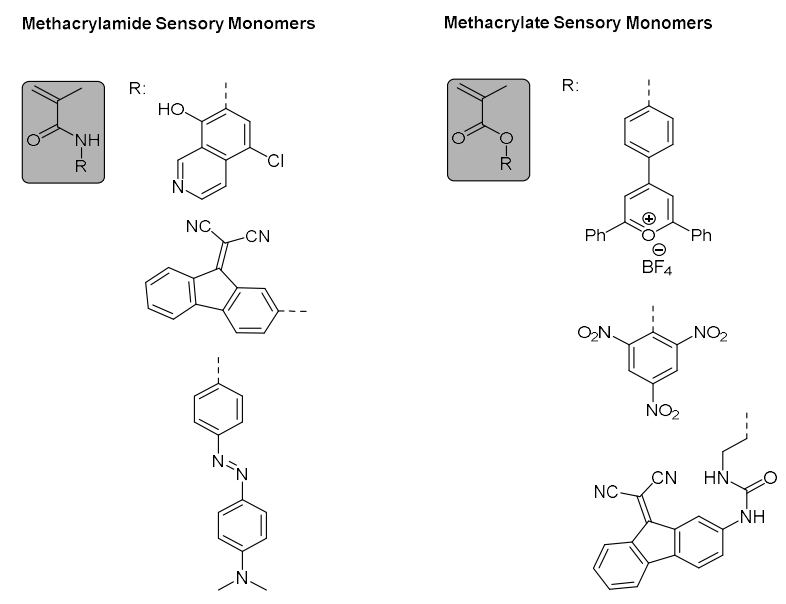

Scheme 1. Some examples of acrylic-based sensory monomers used for preparing sensory polymers for the detection of charged species. 
Conductive polymers are formed by main polymer chains that alternate simple and multiple bonds. In the normal state, these polymers are electrically insulating or semiconductors, but they are easily converted to conductor materials by doping. They also present luminescence, and this physical property, along with the electrical signal derived from the (semi)conductivity, can be used as the output signal in sensory devices. Some of the main conducting polymers include fluorene derivatives (PFs), polyaniline (PAni) or polypyrrole (PPy), as shown in Scheme 2 [12].

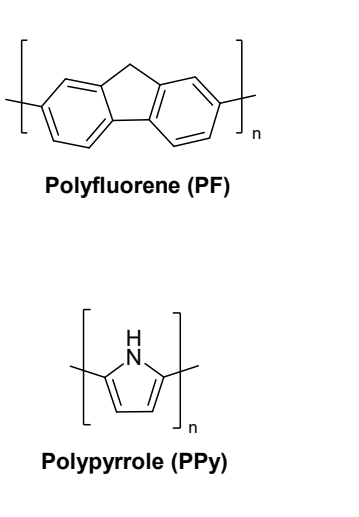

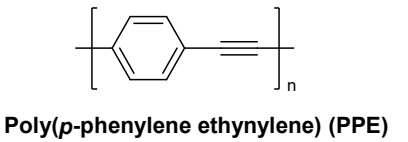

Poly(p-phenylene ethynylene) (PPE)

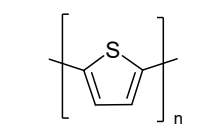

Polytiophene (PT)

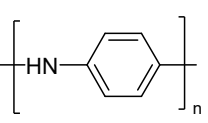

Polyaniline (PAni)

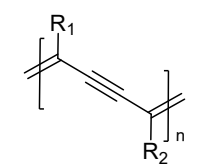

Polydiacetylene (PDA)

Scheme 2. Some typical conducting polymers used as sensors.

In recent years, different ligands have been introduced into the main polymer chain to achieve chiral recognition of important chiral analytes. A description of the different ligands that are currently being employed to obtain sensory polymers, mainly in luminescence and colorimetric sensors, can be found in several works in the literature $[13,14]$.

To conclude this brief introduction to the main sensory polymers that are employed in sensory devices, it is necessary to introduce the sensory arrays, which are based on a set of polymers. This disposition is used when the response of only one type of polymer is not selective or sensitive enough for the application, thus the combination of different polymers in an array produces a more effective sensor, increasing the selectivity and selectivity of the sensing procedure. Sensory arrays are employed in a great variety of applications, from gas detection to biological applications $[15,16]$.

\section{Mechanisms of Detection and Target Species}

The sensing process is based on the change in various physical and chemical properties of the polymers, which vary in the presence of the target species. In this review, the micro and nano sensory devices described are based on the analysis and transduction of this change in physical properties during the sensing process. Following this line, there are different mechanisms of detection that are employed based on different physicochemical characteristics.

First, changes of colorimetric, luminescence (fluorescence or phosphorescence) properties of smart polymers when exposed to target species produces easily quantifiable sensory responses. Color variation depends on selective chemical reactions or specific interactions based on feeble interactions, such as hydrogen bonds. The color change is identifiable by naked-eye or by simple colorimetric techniques (RGB determination) $[17,18]$. On the other hand, in fluorescence sensors, the sensory behavior includes a receptor that recognizes the target, and a fluorophore responsible for the fluorescence signal. In contrast to colorimetric sensors, the sensing must be quantified using fluorescence spectrometers, in terms of the turn-off or quenching of the luminescence (the deactivation of the luminescence [19]), or the opposite effect, the activation (turn-on) of the luminescence of the sensory species $[20,21]$.

Another typical response is based on changes in electrical resistance due to the surface reaction with different chemicals, thus offering the possibility to measure changes in the resistivity of the 
polymer in the presence of different analytes (resistive sensors). In this sense, special organically resistive sensors using conducting polymers (CPs) offer great potential to produce flexible, low-cost and lightweight devices with good mechanical properties and tunable electrical conductivity. A similar detection method is used when employing modified electrodes coated with sensory polymers, thus detecting the sensory response throughout electrochemical measurements, mainly cyclic voltammetry [22].

Finally, an interesting method for detecting different species is the use of piezo-resistive quartz crystal micro balances (QCMs). In these devices, the sensory effect is produced due to the mass change of the polymer when the species is absorbed. The mass change produces a variation in the resonance frequency of the piezoelectric crystal, which can easily be measured and quantified. It is important to use appropriate coating materials on the QCM sensor surfaces, to specifically determine their final properties and applications [23].

A wide variety of target species or analytes can be detected using sensory polymeric materials. In this review, we have selected four main groups of species that are currently under extensive research. Heavy metal cations and anions, gases and organic volatile compounds (VOCs), explosives and chemical warfare agents and finally the recent research concerning the biological and biomedical applications, mainly focused in the immobilization and detection of proteins, glucose and different disease markers.

The optical response (colorimetric and luminescence) in sensory polymers is mainly employed in the detection (in aqueous solution) of heavy metal cations and anions. The detection of these ions is carried out using conducting, hybrid and acrylic polymers. In this sense, copper cations are detected employing different polymeric main structures such as polyacetylene, polypentiptycene ethynylene or polyfluorene derivatives using quenching fluorescence techniques, with detection limits in the range of ppm and ppb [24], whereas the detection of $\mathrm{Zn}^{2+}$ cations is analyzed using polymers containing $(R, R)$-salen-based moieties, which show fluorescence responses when exposed to different zinc cations [25]. Also, sensors based on conducting polyaniline are employed to detect $\mathrm{Hg}^{2+}$ cations, by means of resistivity variation, with very low detection limits (ppb) [26]. The importance of the $\mathrm{Hg}^{2+}$ detection is also reflected in several recent works [27-30]. Finally, other cations such as $\mathrm{Pd}^{2+}$ and $\mathrm{Pt}^{4+}$ are detected through the fluorescence variation of different sensory polymers [31,32].

Resistive sensors are mainly focused on the detection of harmful target gases (such as $\mathrm{NH}_{3}$, $\mathrm{H}_{2} \mathrm{~S}$ or $\mathrm{CO}$ ) and VOCs (such as alcohols, $\mathrm{CO}_{2}$ or environmental humidity). The use of conducting polymers in these resistive devices is especially interesting, producing flexible and low-cost devices with tuned electrical conductivity [33-35]. Some examples include the detection of gases such as hexane or methanol using polymer films with spectroscopic properties [36], the quantification of $\mathrm{CO}_{2}$ in ethanol solutions by means of branched PEI using the turn-on effect of the fluorescence [37], and the detection of humidity using polymeric films based on 4-vinylpyridimium with fast response times [38].

Due to the increasing terrorist menace and the reinforcement of security measures, the detection of explosives and harmful substances, mainly in gas phase, is one of the most important envisaged applications of sensing polymers. Taking into account all the experience acquired in gas sensing, new and different developments have been carried out in this field. For example, films based on pentiptycene and tetraphenylehylene moieties can detect picric acid aqueous media, from the fluorescence quenching effect, with very low detection limits (ppb) [39]. Hydrazine vapors are also detected using a film based in poly(phenyl ethers) [40]. A related research line is focused on the use of films from acrylic polymers to detect TNT vapors and also in aqueous media [41-43].

Other dangerous anions, such as fluorides and cyanides, can also be detected using sensory polymeric materials. For example, fluoride anion $\mathrm{F}^{-}$is detected trough the formation of coumarins in fluorinated poly(phthalazinone ether), activating the fluorescence signal [44]. On the other hand, the detection of $\mathrm{CN}^{-}$using hybrid polymers containing $\mathrm{Cu}^{2+}$ have been carried out using different polymers containing several backbone families, such as functionalized hybrid 
polyacetylene [45], or dicyano-vinyl containing a conjugated polymer [46], with very low detection limits (in the range of $\mathrm{ppb}$ ).

Undoubtedly, the study of biological and biomedical applications of sensory polymers has increased exponentially in the last 10-15 years. Different biomolecules, proteins or, especially, glucose can be detected accurately using different sensory devices based on smart polymers. In this review, we note the most recent works, but it is important to note that this field is evolving quickly. We then include some interesting examples: Folic acid can be detected using a sensor based on MIPs formed by electropolymerization of the thermosensitive amine-terminated poly( $N$-isopropylacrylamide), and then measuring, using cyclic voltammetry techniques, changes in the electrochemical properties in presence of the analyte [47]. Proteins such as myoglobin are detected using nanofilms based on poly(hydroxyethyl methacrylate- $N$-methacryloyl-(L)-tryptophan methyl ester), which is coated on a gold surface. Then, surface plasmon resonance measurements are preformed, detecting the presence of the myoglobin with a sensitivity of $26.3 \mathrm{ng} / \mathrm{mL}$, and also with great selectivity against other species, such as lysozyme, cytochrome and bovine serum albumin. This sensory system has been applied to real samples from myocardial infarction patients [48]. Protein detection is also carried out capturing and quantifying amino acids and neurotransmitters of $X$-linked inhibitors of apoptosis protein, using polymeric sensors with anchored juglone backbones [49]. As stated before, glucose is detected in many different ways, due to the medical importance for the control of diabetes. For example, nano and micro porous shaped polypyrrole films can be used to detect glucose through voltammetry measurements [50]. Hormones such as testosterone are also possible to detect by their ability to bind to an acrylic acid film [51], whereas melamine can be quantified directly in real milk samples using a fluorescent MIP chemosensor based on a rhodamine derivative, with low detection limits $\left(1.55 \times 10^{-4} \mathrm{M}\right)[52]$.

To list the recent works focused in the synthesis and properties of sensory polymers, we present in Table 1 a bibliographic review concerning the use of smart polymers as sensors for the detection of the target species described previously: different cations and anions, gases and volatile organic compounds, explosives and harmful substances and to conclude, the detection of biomolecules.

Table 1. Detection of analytes using sensory polymers. (For additional information, please see reference [53]).

\begin{tabular}{ccc}
\hline Type of Analyte & Target Species & References \\
\hline & $\mathrm{Hg}^{2+}$ & {$[26-30,54-63]$} \\
Cations and anions & $\mathrm{Zn}^{2+}$ & {$[64-69]$} \\
& $\mathrm{Cu}^{2+}$ & {$[20,24,70-74]$} \\
& $\mathrm{Fe}^{2+}, \mathrm{Fe}^{3+}$ & {$[57,73,75-79]$} \\
& $\mathrm{Al}^{3+}$ & {$[58,78,80,81]$} \\
& $\mathrm{Cr}^{3+}, \mathrm{Cr}^{6+}$ & {$[27,58,73,78]$} \\
Gases and Volatile Organic Compounds & $\mathrm{F}^{-}$ & {$[44,82,83]$} \\
& $\mathrm{CN}^{-}$ & {$[45,46,74,84-88]$} \\
& $\mathrm{Other} \mathrm{cations}^{-}$ & {$[19,31,32,72,79,89,90]$} \\
\hline & $\mathrm{NH}_{3}$ & {$[35,91-94]$} \\
& $\mathrm{CO}_{2}$ & {$[37,95,96]$} \\
& $\mathrm{H}_{2} \mathrm{O}$ & {$[38,97-100]$} \\
& $\mathrm{VOCs}^{2}$ & {$[17,18,22,23,36,101-104]$} \\
\hline & $\mathrm{PETN}^{1} / \mathrm{RDX}^{2}$ & {$[105]$} \\
& $\mathrm{TATP}^{3}$ & {$[106]$} \\
& $\mathrm{DCP}^{4}$ & {$[107]$} \\
& $\mathrm{Hydrazine}^{4}$ & {$[21,109,110]$} \\
& $\mathrm{DNB}^{5}, \mathrm{DNT}^{6}$ & {$[41-43,105,110-112]$} \\
\hline
\end{tabular}


Table 1. Cont.

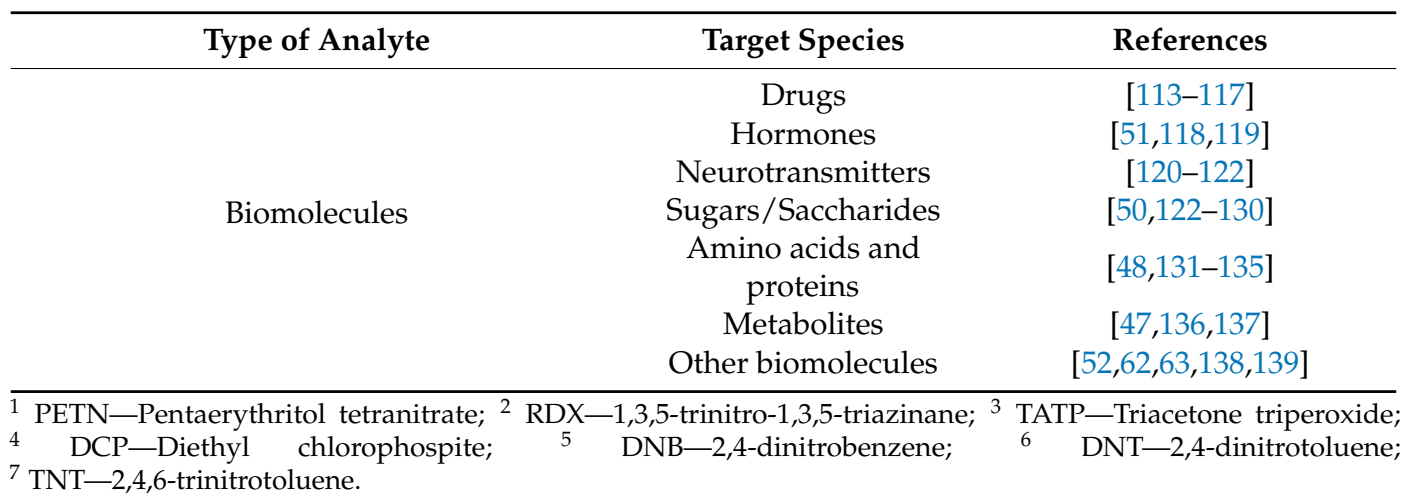

\section{New Micro and Nano Sensory Devices Based on Smart Polymers}

The development of new sensory polymers has opened new possibilities in the preparation of micro- and nanodevices, which are essentially focused on detecting and quantifying different physical properties that change due to the sensing effect. The quantification of these properties is related directly to the amount (sensitivity) and the type (selectivity) of the target species. In this sense, sensory devices based on smart polymers are evolving quickly, and in this review, we will present the most representative. We will analyze the micro- and nanodevices based on polymeric nanofibers, films and coatings, sensory arrays (which are extensively used in electronic noses), QCMs, microfluidic devices, modified electrodes with smart polymers, and also sensory devices based on polymer field-effect transistors. We will also include a brief description of sensory chips, which are gaining interest for biological and biomedical applications, the use of micro and nanoporous materials, and finally a couple of references related to the sensory devices based on LIPSS (Laser Induced Periodic Surface Structures), as well as sensory devices related to the SERS (Surface Enhanced Raman Spectroscopy) effect, which can be used for the sensor enhancement effect. This part of the review will also include a deep bibliographic outlook starting from the early $2000 \mathrm{~s}$ and extending up to the present day, ending with a schematic table covering the most important research works presented in this investigation line.

Polymeric nanofibers present great interest due to their combination of high surface area, large porosity and interconnected porous structure, thus conferring them with high selectivity and sensitivity, reversibility and also fast response time. Different physical properties can be measured using these materials, thus leading to several detection mechanisms. Some of them have already been detailed in at the beginning of Section 3, such as resistive and optical responses. In this case, we also include the surface acoustic wave (SAW) sensors, in which the sensing mechanism is related to the analysis of the change in the velocity of an acoustic wave on a piezoelectric substrate surface, which is caused by the adsorption process of different analytes. There are different applications in which polymeric nanofibers can be used, such as biosensors (especially glucose sensors for the diagnosis and treatment of diabetes, due to the high sensitivity and selectivity to glucose and glucose oxidase). Other analytes detected with these devices are fructose, methanol or hydrazine, and also hormones and amino acids, such as thyroxine and methionine. The review presented by Wang et al. resumes the fabrication process and applications of sensory devices based on nanofibers [140].

Due to their easy processability, polymers can be transformed into films or coatings. In this second case, the sensory monomer, or macromolecules with receptor motifs, is dispersed or anchored, generally in small proportions (up to $5 \mathrm{wt} \%$ ) acting as coating in a given substrate. The deposition takes place usually using spraying or sputtering techniques of the polymer solution using air brushes. The thickness of the coating varies between a few nanometers to $10 \mu \mathrm{m}$. An interesting work has been published by Fitzgerald et al. [36] analyzing the use of polymeric sensory thin films, and also the use of MIPs in sensory applications is investigated in the review paper published by Ye and Mosbach [141]. Concerning use of polymeric films, these materials are produced through a radical polymerization 
of the monomers together with the sensory monomer, which is subsequently employed in the detection, through the different mechanisms (colorimetry, fluorescence, etc.), explained previously. These materials are mainly employed for the detection of several vapors or substances in aqueous media. Polymeric films are obtained with thicknesses of up to $100 \mu \mathrm{m}$, and can be modulated in terms of flexibility, hydrophilicity or transparency.

As seen at the end of Section 2, sensory arrays are finding interesting applications in many research fields, due to their versatility and the possibility of detecting, using a single device, different species. A sensory array consists, basically, of a device containing several sensory polymers, thus broadening the number of analytes that can be detected using a single device. In this way, in biomedicine sensory chips arrays are used to detect different proteins and clinically relevant biomolecules to prevent the apparition of diseases [142]. At this point, it is necessary to remark on a specific type of sensory array that has been recently developed, denoted electronic noses, which are specifically focused on the detection of odors and flavors. The scientific development and industrial applications have increased in parallel during the last decade, as shown in the review published by Arshak et al. [143], with special attention to a specific application that has attracted a lot of interest concerning the characterization of olive oil and wine, as described in the review work presented by Rodríguez-Méndez et al. [144].

QCMs are employed as sensory devices taking advantage of the piezoelectric effect. In these devices, the sensory effect is produced due to a mass change of the polymer when the target species is detected, thus originating an electrical signal (change of resonance frequency) that can be easily measured and quantified. In QCM sensors, the smart polymer directly coats the substrate, and detecting an electrical signal shortens the response time, enhances the sensitivity, and also reduces the variability. Sensory devices based on QCMs modified with smart polymers are being employed in a great number of applications. For example, in the detection of organic vapors and harmful gases, as described in the review of Nanto et al. [145], in biological applications such the immobilization of antibodies and DNA, and also in the detection of heavy metal ions (copper, cadmium or gold cations), as described in several published works [146,147].

Microfluidic and nanofluidic technologies emerged in the early $2000 \mathrm{~s}$, and have recently become a very interesting fabrication technique for obtaining micro and nano sensory devices based on smart polymers. Although the detection methods employed in these devices have already been described, electrochemical measurements enhance their selectivity and sensitivity, and for this reason, they are widely used. This detection method is based on the electrical modulation of the analyte species that occurs under redox reactions, with electroactive species being detected through cyclic voltammetry measurements. Two main applications have recently been the focus of research efforts. First, biological and biomedical applications, such as the detection of proteins and glucose [127,128], including a deep review published recently covering the applications of the sensory systems integrated in microfluidic devices [148]. The other interesting applications follows a classical research line described previously, and is focused on the detection of heavy metal ions, which is crucial for environmental and safety reasons [149]. Following this line, in situ measurements, especially, for controlling environmental pollution, have gained interest, as detailed in the review recently published on this topic [150].

Another type of sensory devices uses modified electrodes with smart polymers. In these sensory devices, analytical methods allow the utilization of electrochemical measurements (cyclic voltammetry) to determine the sensing effect by means of electrical signals, thus improving the detection and quantification experiments. The modification of these electrodes can be done in several ways, and using different materials, as described in the review published in 2016 by Naveen et al. [151]. Non-modified electrodes based on metal or graphene are coated with sensory polymers, (conducting polymers or polymer nanocomposites), then the electrochemical properties are measured, and the voltammetry results are correlated directly with the detection and quantification properties of the sensor. The applications in which these sensory devices are employed have been also increased greatly in the last decade. For example, detection of heavy metal ions (such as palladium), is carried out using graphene modified electrodes [152]. The detection of VOCs, such as phenol, ethanol or 
methanol is also analyzed using modified electrodes, as well as the quantification of quantification of humidity, which is carried out using electrodes modified with conducting polymers [99]. Finally, as seen throughout all of this review, biological applications, mainly protein detection, are currently under investigation using these devices. We can remark on applications concerning the electrochemical biosensing of glucose and lactic acid [153] and different medications and drugs, such as anticancer substances [154] or phenobarbital [155]. A deep bibliographic review was published in 2016, with special attention given to biological and biomedical applications [156]. Additionally, following this line, the use of polymer field-effect transistors has gained a lot of attention in recent years, with different works being published related to the detection of $\mathrm{H}_{2} \mathrm{~S}$ and ammonia $[157,158]$. A review focused on gas sensors based on these devices has recently been published by Lv et al. [159].

Two other interesting and emerging sensory devices are the so-called sensory chips and the sensory devices based on microporous and nanoporous materials. Concerning sensory chips, these are handleable devices that can be used directly on human skin to carry out in situ biological analysis (detection of proteins or immobilization of disease markers), and also temperature monitoring. It is important to remark that chips can be also developed in the form of sensory arrays, thus detecting different biological molecules using a single chip. For these reasons, they have attracted special attention in the last years, with an incipient development. A detailed list of recent research papers will be detailed next, but we will remark on the review published in 2015 by Chuan-Guang et al., devoted to the analysis and detection of azobenzene derivatives using polymeric sensing chips [160], as well as an interesting research paper presented by Song et al. concerning antigen-antibody recognition using biological chips based on poly( $N$-isopropylacrylamide) [161]. Another interesting research line investigates the use of micro- and nanoporous materials in sensory devices. These materials present several advantages over traditional sensors, especially the increased interfacial area, which leads to higher sensitivity compared to solid materials. The use of microporous and nanoporous materials is specifically focused on developing new porous substrates in which the sensory polymer is deposited. Some examples of applications include the detection of nitroaromatic vapors [111] or the immobilization and quantification of lipids [162].

To conclude this section, we detail in Table 2 the publications covering the new micro and nano sensory devices based on smart polymers, following the scheme presented previously: devices based on polymer nanofibers, polymer films and coatings, sensory polymeric arrays, modified quartz crystal microbalances, sensory devices prepared from microfluidic techniques, the use of modified electrodes coated with sensory polymers, sensory chips and finally sensory devices based on microand nanoporous materials.

Table 2. Overview of micro and nano sensory devices using smart polymers. (For additional information, please see references $[141,144,145,148,150,151,156,160])$.

\begin{tabular}{ccc}
\hline Group of Sensory Devices & Type of Response & References \\
\hline \multirow{2}{*}{ Polymer nanofibers } & SAW & {$[163,164]$} \\
& Electrical & {$[34,35,118,165-167]$} \\
& Optical & {$[17-19,168]$} \\
\hline \multirow{2}{*}{ Polymer films and coatings } & Optical & {$[39,48,169-176]$} \\
& Electrochemical & {$[115,177-179]$} \\
& Electrical & {$[93]$} \\
\hline \multirow{2}{*}{ Sensory polymeric arrays } & Optical & {$[89,180-182]$} \\
& Electrical & {$[183-185]$} \\
\hline Quartz Crystal Microbalances & Piezoelectric & {$[14,114,130,146,186-192]$} \\
\hline \multirow{2}{*}{ Microfluidic devices } & Optical & {$[27,128,150,193-195]$} \\
& Electrical & {$[148,190]$} \\
\hline Modified electrodes & Electrochemical & {$[26,99,152-155,196-202]$} \\
\hline Sensory chips & Optical & {$[161,193-195]$} \\
\hline
\end{tabular}


Table 2. Cont.

\begin{tabular}{ccc}
\hline Group of Sensory Devices & Type of Response & References \\
\hline \multirow{2}{*}{ Micro and nanoporous materials } & Optical & {$[111,203-205]$} \\
& Electrochemical & {$[162,206]$} \\
\hline LIPSS and SERS effect & Optical & {$[207,208]$} \\
\hline
\end{tabular}

\section{Conclusions}

The present review has focused on the analysis of recent developments in the research and development of sensory polymers and the preparation of micro and nano sensory devices using these smart materials. It has been remarked that in the last 10-15 years, the interest in this research field has increased noticeably, with a great number of publications and review articles published to date. Apart from classical applications in gas or metal cation detection, the emerging field related to biological and biomedical applications is especially interesting. In parallel, the improvement in the experimental techniques to determine optical, electrical or mechanical properties have enhanced the sensitivity and selectivity of the sensory devices.

It is important not to forget the difficulties and challenges that must be overcome in these devices, such as the improvement of selectivity, the increasing of the number of target species, with special attention on biomedical and biological applications, and also the reduction of the detection or response time. These research advancements should be carried out together with the industrial applications, then improving the production methods in order to obtain and commercialize cheap and portable sensory devices.

Acknowledgments: The financial support provided by FEDER (Fondo Europeo de DEsarrollo Regional), and both the Spanish Ministerio de Economía, Industria y Competitividad (MAT2014-54137-R, MAT2017-84501-R) and the Consejería de Educación-Junta de Castilla y León (BU061U16) is gratefully acknowledged.

Author Contributions: J.A.R.R. and S.V. wrote the review article; A.M.S. carried out the bibliographic search to include in the review; F.C.G. and J.M.G. conceived, revised and corrected the final version of the article.

Conflicts of Interest: The authors declare no conflict of interest.

\section{References}

1. Okatno, T. Molecular design of temperature-responsive polymers as intelligent materials. In Advances in Polymer Chemistry, 1st ed.; Dušek, K., Ed.; Springer: Berlin, Germany, 1993; pp. 180-197, ISBN 978-3-540-47836-2.

2. Thévenot, J.; Oliveira, H.; Sandre, O.; Lecommandoux, S. Magnetic responsive polymer composite materials. Chem. Soc. Rev. 2013, 42, 7099-7116. [CrossRef] [PubMed]

3. Colson, Y.L.; Grinstaff, M.W. Biologically responsive polymeric nanoparticles for drug delivery. Adv. Mater. 2012, 24, 3878-3886. [CrossRef] [PubMed]

4. Dai, S.; Ravi, P.; Tam, K.C. pH-Responsive polymers: Synthesis, properties and applications. Soft Matter 2008, 4, 435-449. [CrossRef]

5. Hu, J.; Liu, S. Responsive polymers for detection and sensing applications: Current status and future developments. Macromolecules 2010, 43, 8315-8330. [CrossRef]

6. Chaterji, S.; Kwon, I.K.; Park, K. Smart polymeric gels: Redefining the limits of biomedical devices. Prog. Polym. Sci. 2007, 32, 1083-1122. [CrossRef] [PubMed]

7. Bajpai, A.K.; Sandeep, K.S.; Bhanu, S.; Kankane, S. Responsive polymers in controlled drug delivery. Prog. Polym. Sci. 2008, 33, 1088-1118. [CrossRef]

8. García, J.M.; Pablos, J.L.; García, F.C.; Serna, F. Sensory polymers for detecting explosives and chemical warfare agents. In Industrial Applications for Intelligent Polymers and Coatings, 1st ed.; Hosseini, M., Makhlouf, A.S., Eds.; Springer International Publishing: Basel, Switzerland, 2016; pp. 553-576, ISBN 978-3-319-26893-4. 
9. García, J.M.; García, F.C.; Serna, F.; de la Peña, J.L. Fluorogenic and chromogenic polymer chemosensors. Polym. Rev. 2011, 51, 341-390. [CrossRef]

10. Uzun, L.; Turner, A.P. Molecularly-imprinted polymer sensors: Realizing their potential. Biosens. Bioelectron. 2016, 76, 131-144. [CrossRef] [PubMed]

11. Dai, J.; Zhang, T.; Zhao, H.; Fei, T. Preparation of organic-inorganic hybrid polymers and their humidity sensing properties. Sens. Actuators B Chem. 2017, 242, 1108-1114. [CrossRef]

12. Balint, R.; Cassidy, N.; Cartmell, S. Conductive polymers: Towards a smart biomaterial for tissue engineering. Acta Biomater. 2014, 10, 2341-2353. [CrossRef] [PubMed]

13. Zhang, X.; Yin, J.; Yoon, J. Recent advances in development of chiral fluorescent and colorimetric sensors. Chem. Rev. 2014, 114, 4918-4959. [CrossRef] [PubMed]

14. Xu, Y.; Zheng, L.; Huang, X.; Cheng, Y.; Zhu, C. Fluorescence sensors based on chiral polymer for highly enantioselective recognition of phenylglycinol. Polymer 2010, 51, 994-997. [CrossRef]

15. Greene, N.T.; Shimizu, K.D. Colorimetric molecularly imprinted polymer sensor array using dye displacement. J. Am. Chem. Soc. 2005, 127, 5695-5700. [CrossRef] [PubMed]

16. Woodka, M.D.; Schnee, V.P.; Polcha, M.P. Fluorescent polymer sensor array for detection and discrimination of explosives in water. Anal. Chem. 2010, 82, 9917-9924. [CrossRef] [PubMed]

17. Wang, X.; Si, Y.; Wang, J.; Ding, B.; Yu, J.; Al-Deyab, S.S. A facile and highly sensitive colorimetric sensor for the detection of formaldehyde based on electro-spinning/netting nano-fiber/nets. Sens. Actuators B Chem. 2012, 163, 186-193. [CrossRef]

18. Yoon, J.; Chae, S.; Kim, J.-M. Colorimetric sensors for volatile organic compounds (VOCs) based on conjugated polymer-embedded electrospun fibers. J. Am. Chem. Soc. 2007, 129, 3038-3039. [CrossRef] [PubMed]

19. Adewuyi, S.; Ondigo, D.; Zugle, R.; Tshentu, Z.; Nyokong, T.; Torto, N. A highly selective and sensitive pyridylazo-2-naphthol-poly(acrylic acid) functionalized electrospun nanofiber fluorescence "turn-off" chemosensory system for $\mathrm{Ni}^{2+}$. Anal. Meth. 2012, 4, 1729-1735. [CrossRef]

20. Wang, W.; Yang, Q.; Sun, L.; Wang, H.; Zhang, C.; Fei, X.; Li, Y. Preparation of fluorescent nanofibrous film as a sensing material and adsorbent for $\mathrm{Cu}(\mathrm{II})$ in aqueous solution via copolymerization and electrospinning. J. Hazard. Mater. 2011, 194, 185-192. [CrossRef] [PubMed]

21. Chu, F.; Tsiminis, G.; Spooner, N.A.; Monro, T.M. Explosives detection by fluorescence quenching of conjugated polymers in suspended core optical fibers. Sens. Actuators B Chem. 2014, 199, 22-26. [CrossRef]

22. Geng, L.; Zhao, Y.; Huang, X.; Wang, S.; Zhang, S.; Wu, S. Characterization and gas sensitivity study of polyaniline $/ \mathrm{SnO}_{2}$ hybrid material prepared by hydrothermal route. Sens. Actuators B Chem. 2007, 120, 568-572. [CrossRef]

23. Khot, L.R.; Panigrahi, S.; Lin, D. Development and evaluation of piezoelectric-polymer thin film sensors for low concentration detection of volatile organic compounds related to food safety applications. Sens. Actuators B Chem. 2011, 153, 1-10. [CrossRef]

24. Chen, A.; Wu, W.; Fegley, M.E.; Pinnock, S.S.; Duffy-Matzner, J.L.; Bernier, W.E.; Jones, W.E., Jr. Pentiptycene-derived fluorescence turn-off polymer chemosensor for copper(II) cation with high selectivity and sensitivity. Polymers 2017, 9, 118. [CrossRef]

25. Xu, Y.; Meng, J.; Meng, L.; Dong, Y.; Cheng, Y.; Zhu, C. A highly selective fluorescence-based polymer sensor incorporating an $(R, R)$-Salen moiety for $\mathrm{Zn}^{2+}$ detection. Chem. Eur. J. 2010, 16, 12898-12903. [CrossRef] [PubMed]

26. Somerset, V.; Leaner, J.; Mason, R.; Iwuoha, E.; Aoife, M. Determination of inorganic mercury using a polyaniline and polyaniline-methylene blue coated screen-printed carbon electrode. Int. J. Environ. Anal. Chem. 2010, 90, 671-685. [CrossRef]

27. Petzoldt, M.; Eschenbaum, C.; Schwaebel, S.T.; Broedner, K.L.; Hamburger, M.; Bunz, U.H. A biphasic mercury-ion sensor: Exploiting microfluidics to make simple anilines competitive ligands. Chem. Eur. J. 2015, 21, 14297-14300. [CrossRef] [PubMed]

28. Vallejos, S.; Reglero, J.A.; García, F.C.; García, J.M. Direct visual detection and quantification of mercury in fresh fish meat using facilely prepared polymeric sensory labels. J. Mater. Chem. A 2017, 5, 13710-13716. [CrossRef] 
29. Coronado, E.; Galán-Mascarós, J.R.; Martí-Gastaldo, C.; Palomares, E.; Durrant, J.R.; Vilar, R.; Gratzel, M.; Nazeeruddin, K. Reversible colorimetric probes for mercury sensing. J. Am. Chem. Soc. 2005, 127, 12351-12356. [CrossRef] [PubMed]

30. Ma, X.; Song, F.; Wang, L.; Cheng, Y.; Zhu, C. Polymer-based colorimetric and "turn-off" fluorescence sensor incorporating benzo[2,1,3]thiadiazole moiety for $\mathrm{Hg}^{2+}$ detection. J. Polym. Sci. Part A Polym. Chem. 2012, 50, 517-522. [CrossRef]

31. Liu, B.; Dai, H.; Bao, Y.; Du, F.; Tian, R.; Bai, R. 2,6-Substituted pyridine derivative-containing conjugated polymers: Synthesis, photoluminescence and ion-sensing properties. Polym. Chem. 2011, 2, 1699-1705. [CrossRef]

32. Liu, B.; Dai, H.; Bao, Y.; Wang, H.; Du, F.; Tian, J.; Li, Q.; Bai, R. An efficient conjugated polymer sensor based on the aggregation-induced fluorescence quenching mechanism for the specific detection of palladium and platinum ions. J. Mater. Chem. 2012, 22, 3555-3561. [CrossRef]

33. Lin, Q.; Li, Y.; Yang, M. Polyaniline nanofiber humidity sensor prepared by electrospinning. Sens. Actuators B Chem. 2012, 161, 967-972. [CrossRef]

34. Liu, H.; Kameoka, J.; Czaplewski, D.A.; Craighead, H.G. Polymeric nanowire chemical sensor. Nano Lett. 2004, 4, 671-675. [CrossRef]

35. Xue, M.; Li, F.; Wang, Y.; Cai, X.; Pan, F.; Chen, J. Ultralow-limit gas detection in nano-dumbbell polymer sensor via electrospinning. Nanoscale 2013, 5, 1803-1805. [CrossRef] [PubMed]

36. Fitzgerald, J.E.; Zhu, J.; Bravo-Vasquez, J.P. Cross-reactive, self-encoded polymer film arrays for sensor applications. RSC Adv. 2016, 6, 82616-82624. [CrossRef]

37. Lu, W.; Xiao, P.; Gu, J.; Zhang, J.; Huang, Y.; Huang, Q.; Chen, T. Aggregation-induced emission of tetraphenylethylene-modified polyethyleneimine for highly selective $\mathrm{CO}_{2}$ detection. Sens. Actuators B Chem. 2016, 228, 551-556. [CrossRef]

38. Fei, T.; Dai, J.; Jiang, K.; Zhao, H.; Zhang, T. Stable cross-linked amphiphilic polymers from a one-pot reaction for application in humidity sensors. Sens. Actuators B Chem. 2016, 227, 649-654. [CrossRef]

39. Ghosh, K.R.; Saha, S.K.; Wang, Z.Y. Ultra-sensitive detection of explosives in solution and film as well as the development of thicker film effectiveness by tetraphenylethene moiety in AEI active fluorescent conjugated polymer. Polym. Chem. 2014, 5, 5638-5643. [CrossRef]

40. Thomas, S.W.; Swager, T.M. Trace hydrazine detection with fluorescent conjugated polymers: A turn-on sensory mechanism. Adv. Mater. 2006, 18, 1047-1050. [CrossRef]

41. Pablos, J.L.; Trigo-López, M.; Serna, F.; García, F.C.; García, J.M. Solid polymer substrates and smart fibres for the selective visual detection of TNT both in vapor and in aqueous media. RSC Adv. 2014, 4, 25562-25568. [CrossRef]

42. Pablos, J.L.; Trigo-López, M.; Serna, F.; García, F.; García, J.M. Water-soluble polymers, solid polymer membranes, and coated fibres as smart sensory materials for the naked eye detection and quantification of TNT in aqueous media. Chem. Commun. 2014, 50, 2484-2487. [CrossRef] [PubMed]

43. Pablos, J.L.; Vallejos, S.; Muñoz, A.; Rojo, M.J.; Serna, F.; García, F.C.; García, J.M. Solid polymer substrates and coated fibers containing 2,4,6-trinitrobenzene motifs as smart labels for the visual detection of biogenic amine vapors. Chem. Eur. J. 2015, 21, 8733-8736. [CrossRef] [PubMed]

44. Kim, T.H.; Swager, T.M. A fluorescent self-amplifying wavelength-responsive sensory polymer for fluoride ions. Angew. Chem. Int. Ed. 2003, 115, 4951-4954. [CrossRef]

45. Zeng, Q.; Cai, P.; Li, Z.; Qin, J.; Tang, B.Z. An imidazole-functionalized polyacetylene: Convenient synthesis and selective chemosensor for metal ions and cyanide. Chem. Commun. 2008, 9, 1094-1096. [CrossRef] [PubMed]

46. Wu, X.; Xu, B.; Tong, H.; Wang, L. Highly selective and sensitive detection of cyanide by a reaction-based conjugated polymer chemosensor. Macromolecules 2011, 44, 4241-4248. [CrossRef]

47. Karimian, N.; Zavar, M.H.A.; Chamsaz, M.; Turner, A.P.; Tiwari, A. On/off-switchable electrochemical folic acid sensor based on molecularly imprinted polymer electrode. Electrochem. Commun. 2013, 36, 92-95. [CrossRef]

48. Osman, B.; Uzun, L.; Besirli, N.; Denizli, A. Microcontact imprinted surface plasmon resonance sensor for myoglobin detection. Mater. Sci. Eng. C 2013, 33, 3609-3614. [CrossRef] [PubMed] 
49. Wang, X.; Piro, B.; Reisberg, S.; Anquetin, G.; de Rocquigny, H.; Jiang, P.; Dong, C.Z. Direct, reagentless electrochemical detection of the BIR3 domain of X-linked inhibitor of apoptosis protein using a peptide-based conducting polymer sensor. Biosens. Bioelectron. 2014, 61, 57-62. [CrossRef] [PubMed]

50. Cysewska, C.; Karczewski, J.; Jasiński, P. Electrochemical synthesis of 3D nano-/micro-structured porous PPy. Mater. Lett. 2016, 183, 397-400. [CrossRef]

51. Fuchs, Y.; Soppera, O.; Mayes, A.G.; Haup, K. Holographic molecularly imprinted polymers for label-free chemical sensing. Adv. Mater. 2013, 25, 566-570. [CrossRef] [PubMed]

52. Sun, K.; Deng, Q.; Guo, T.; Su, R.; Gu, Y.; Wang, S. High selectivity and sensitivity fluorescence sensing of melamine based on the combination of a fluorescent chemosensor and molecularly imprinted polymers. RSC Adv. 2015, 5, 94084-94090. [CrossRef]

53. Liu, C.-L.; Lin, C.-H.; Kuo, C.-C.; Lin, S.-T.; Chen, W.-C. Conjugated rod-coil block copolymers: Synthesis, morphology, photophysical properties, and stimuli-responsive applications. Prog. Polym. Sci. 2011, 36, 603-637. [CrossRef]

54. Li, D.; Li, H.; Liu, M.; Chen, J.; Ding, J.; Huang, X.; Wu, H. A novel D- $\pi$-A conjugated polymer chemosensor based on benzo[c][1,2,5]selenadiazole for highly selective and sensitive recognition of mercury(II) ions. Macromol. Chem. Phys. 2014, 215, 82-89. [CrossRef]

55. El Kaoutit, H.; Estévez, P.; García, F.; Serna, F.; García, J. Sub-ppm quantification of Hg(II) in aqueous media using both the naked eye and digital information from pictures of a colorimetric sensory polymer membrane taken with the digital camera of a conventional mobile. Anal. Meth. 2013, 5, 54-58. [CrossRef]

56. Geng, T.M.; Wu, D.Y. Water-soluble polymeric chemosensor for selective detection of $\mathrm{Hg}^{2+}$ in aqueous solution using rhodamine-based modified poly(acrylamide-acrylic acid). Luminescence 2015, 30, 1263-1268. [CrossRef] [PubMed]

57. Geng, T.M.; Guo, C.; Dong, Y.J.; Chen, M.; Wang, Y. Turn-on fluorogenic and chromogenic detection of cations in complete water media with poly $(N$-vinyl pyrrolidone) bearing rhodamine B derivatives as polymeric chemosensor. Polym Adv Technol. 2016, 27, 90-97. [CrossRef]

58. Geng, T.M.; Zhang, W.Y.; Li, D.K.; Xia, H.Y.; Wang, Y.; Wang, Z.Q.; Zheng, Q. The chromogenic and fluorescent sensing properties for a water soluble polymeric chemosensor bearing rhodamine ethanediamine moieties with oxethyl $\left(\mathrm{OCH}_{2} \mathrm{CH}_{2}\right)$ as a spacer. J. Environ. Chem. Eng. 2017, 5, 906-914. [CrossRef]

59. Vallejos, S.; Estévez, P.; Ibeas, S.; Muñoz, A.; García, F.C.; Serna, F.; García, J.M. A selective and highly sensitive fluorescent probe of $\mathrm{Hg}^{2+}$ in organic and aqueous media: The role of a polymer network in extending the sensing phenomena to water environments. Sens. Actuators B Chem. 2011, 157, 686-690. [CrossRef]

60. Pablos, J.L.; Ibeas, S.; Muñoz, A.; Serna, F.; García, F.C.; García, J.M. Solid polymer and metallogel networks based on a fluorene derivative as fluorescent and colourimetric chemosensors for $\mathrm{Hg}(\mathrm{II})$. React. Funct. Polym. 2014, 79, 14-23. [CrossRef]

61. Abbas, K.; Znad, H.; Awual, Md. R. A ligand anchored conjugate adsorbent for effective mercury(II) detection and removal from aqueous media. Chem. Eng. J. 2018, 334, 432-443. [CrossRef]

62. Li, J.; Wu, Y.; Song, F.; Wei, G.; Cheng, Y.; Zhu, C. A highly selective and sensitive polymer-based OFF-ON fluorescent sensor for $\mathrm{Hg}^{2+}$ detection incorporating salen and perylenyl moieties. J. Mater. Chem. 2012, 22, 478-482. [CrossRef]

63. Jiao, J.; Li, F.; Zhang, S.; Quan, Y.; Zhen, W.; Cheng, Y.; Zhu, C. $\mathrm{Hg}^{2+}$-Induced in situ generated radical cation of (S)-BINOL-based polymer for highly enantioselective recognition of phenylalaninol. Macromol. Rapid Commun. 2014, 35, 1443-1449. [CrossRef] [PubMed]

64. Wang, N.; Kanhere, E.; Kottapalli, A.G.P.; Miao, J.; Triantayllou, M.S. Flexible liquid crystal polymer-based electrochemical sensor for in-situ detection of zinc(II) in seawater. Microchimica Acta 2017, 184, 3007-3015. [CrossRef]

65. Sakthivel, S.; Punniyamurthy, T. Fluorescent OFF-ON polymer chemosensor bonded alternatively with 1,4-dioctyloxybenzene and $(R, R)$-salen for cascade $\mathrm{Zn}^{2+}$ and chiral recognition. Tetrahedron Asymmetry 2012, 23, 570-576. [CrossRef]

66. Song, F.; Ma, X.; Hou, J.; Huang, X.; Cheng, Y.; Zhu, C. $(R, R)$-salen/salan-based polymer fluorescence sensors for $\mathrm{Zn}^{2+}$ detection. Polymers 2011, 52, 6029-6036. [CrossRef] 
67. Sakthivel, S.; Jammi, S.; Punniyamurthy, T. Fluorescent non-linear chiral polymer chemosensor bonded alternatively with 1,4-diethynyl-2,5-dioctyloxybenzene and $(R, R)$-salen for $\mathrm{Zn}^{2+}$ recognition. Tetrahedron Asymmetry 2012, 23, 101-107. [CrossRef]

68. Dong, Y.; Wu, Y.; Jiang, X.; Huang, X.; Cheng, Y.; Zhu, C. A polymer based fluorescent sensor for Zn ${ }^{2+}$ detection and its application for constructing logic gates. Polymer 2011, 52, 5811-5816. [CrossRef]

69. Liu, T.; Liu, S. Responsive polymers-based dual fluorescent chemosensors for $\mathrm{Zn}^{2+}$ ions and temperatures working in purely aqueous media. Anal. Chem. 2011, 83, 2775-2785. [CrossRef] [PubMed]

70. Li, G.; Tao, F.; Wang, H.; Wang, L.; Zhang, J.; Ge, P.; Sung, S. A novel reversible colorimetric chemosensor for the detection of $\mathrm{Cu}^{2+}$ based on a water-soluble polymer containing rhodamine receptor pendants. RSC Adv. 2015, 5, 18983-18989. [CrossRef]

71. Sergeev, A.A.; Mironenko, A.Y.; Leonov, A.A.; Nazirov, A.E.; Voznesenskiy, S.S.; Bratskaya, S.Y.; Kulchin, Y.N. Special features of copper(II) detection in aqueous solutions. Phys. Procedia 2017, 86, 152-154. [CrossRef]

72. Trigo-López, M.; Muñoz, A.; Ibeas, S.; Serna, F.; García, F.C.; García, J.M. Colorimetric detection and determination of $\mathrm{Fe}(\mathrm{III}), \mathrm{Co}(\mathrm{II}), \mathrm{Cu}(\mathrm{II}), \mathrm{Sn}(\mathrm{II})$ in aqueous media by acrylic polymers with pendant terpyridine motifs. Sens. Actuators B Chem. 2016, 8, 118-126. [CrossRef]

73. Barrio-Manso, J.L.; Calvo, P.; García, F.C.; Pablos, J.L.; Torroba, T.; García, J.M. Functional fluorescent aramids: Aromatic polyamides containing a dipicolinic acid derivative as luminescent converters and sensory materials for the fluorescence detection and quantification of $\mathrm{Cr}(\mathrm{VI}), \mathrm{Fe}(\mathrm{III}), \mathrm{Cu}(\mathrm{II})$. Polym. Chem. 2013, 4, 4256-4264. [CrossRef]

74. Chakraborty, C.; Singh, P.; Maji, S.K.; Malik, S. Conjugated polyfluorene-based reversible fluorescent sensor for $\mathrm{Cu}$ (II) and cyanide ions in aqueous medium. Chem. Lett. 2013, 42, 1355-1357. [CrossRef]

75. El Kaoutit, H.; Estévez, P.; Ibeas, S.; García, F.C.; Serna, F.; Benabdelouahab, F.B.; García, J.M. Chromogenic and fluorogenic detection of cations in aqueous media by means of an acrylic polymer chemosensor with pendant Rhodamine-based dyes. Dyes Pigm. 2013, 96, 414-423. [CrossRef]

76. Vallejos, S.; Muñoz, A.; Ibeas, S.; Serna, F.; García, F. Solid sensory polymer substrates for the quantification of iron in blood, wine and water by a scalable RGB technique. J. Mater. Chem. A 2013, 1, 15435-15441. [CrossRef]

77. Ghosh, S.; Dey, C.K.; Manna, R. Epoxy-based polymer bearing 1-napthylamine units: Highly selective fluorescent chemosensor for ferric ion. Tetrahedron Lett. 2010, 51, 3177-3180. [CrossRef]

78. Wang, L.; Li, F.; Liu, X.; Wei, G.; Cheng, Y.; Zhu, C. A helical chiral polymer-based chromo-fluorescence and CD response sensor for selective detection of trivalent cations. J. Polym. Sci. Part A: Polym. Chem. 2013, 51, 4070-4075. [CrossRef]

79. Li, Y.; Ashizawa, M.; Uchida, S.; Michinobu, T. A novel polymeric chemosensor: Dual colorimetric detection of metal ions through click synthesis. Macromol. Rapid Commun. 2011, 32, 1804-1808. [CrossRef] [PubMed]

80. Vallejos, S.; Muñoz, A.; Ibeas, S.; Serna, F.; García, F.C.; García, J.M. Selective and sensitive detection of aluminium ions in water via fluorescence "turn-on" with both solid and water soluble sensory polymer substrates. J. Hazard. Mater. 2014, 276, 52-57. [CrossRef] [PubMed]

81. Vallejos, S.; Muñoz, S.; Ibeas, S.; Serna, F.; García, F.; García, J.M. Forced solid-state interactions for the selective "Turn-On" fluorescence sensing of aluminum ions in water using a sensory polymer substrate. ACS Appl. Mater. Interfaces 2015, 7, 921-928. [CrossRef] [PubMed]

82. Li, F.; Wei, G.; Sheng, Y.; Quan, Y.; Cheng, Y.; Zhu, C. (S)-Binapthalene-based fluorescence polymer sensors for direct and visual $\mathrm{F}^{-}$detection. Polymer 2014, 55, 5689-5694. [CrossRef]

83. Alaei, P.; Rouhani, S.; Gharanjig, K.; Ghasemi, J. A new polymerizable fluorescent PET chemosensor of fluoride $\left(\mathrm{F}^{-}\right)$based on naphthalimide-thiourea dye. Spectrochim. Acta Part A 2012, 90, 85-92. [CrossRef] [PubMed]

84. Trigo-López, M.; Muñoz, A.; Mendía, A.; Ibeas, S.; Serna, F.; García, F.; García, J.M. Palladium-containing polymers as hybrid sensory materials (water-soluble polymers, films and smart textiles) for the colorimetric detection of cyanide in aqueous and gas phases. Sens. Actuators B Chem. 2017, 255, 2750-2755. [CrossRef]

85. Vallejos, S.; Estévez, P.; García, F.C.; Serna, F.; De la Peña, J.; García, J.M. Putting to work organic sensing molecules in aqueous media: Fluorene derivative-containing polymers as sensory materials for the colorimetric sensing of cyanide in water. Chem. Commun. 2010, 46, 7951-7953. [CrossRef] [PubMed] 
86. Vallejos, S.; El Kaoutit, H.; Estévez, P.; García, F.C.; De la Peña, J.L.; Serna, F.; García, J.M. Working with water insoluble organic molecules in aqueous media: Fluorene derivative-containing polymers as sensory materials for the colorimetric sensing of cyanide in water. Polym. Chem. 2011, 2, 1129-1138. [CrossRef]

87. Son, J.H.; Jang, G.; Lee, T.S. Synthesis of water-soluble, fluorescent, conjugated polybenzodiazaborole for detection of cyanide anion in water. Polymer 2013, 54, 3542-3547. [CrossRef]

88. Lin, Q.; Zhong, K.-P.; Zhu, J.-H.; Ding, L.; Su, J.-X.; Yao, H.; Wei, T.-B.; Zhang, Y.-M. Iodine controlled pillar[5]arene-based multiresponsive supramolecular polymer for fluorescence detection of cyanide, mercury and cysteine. Macromolecules 2017, 50, 7863-7871. [CrossRef]

89. Xu, H.; Wu, W.; Chen, Y.; Qiu, T.; Fan, L. Construction of response patterns for metal cations by using a fluorescent conjugated polymer sensor array from parallel combinatorial synthesis. Appl. Mater. Interfaces 2014, 6, 5041-5049. [CrossRef] [PubMed]

90. Zhang, L.; Li, J.; Ying, Z.; Meng, L.; Fu, C. Highly selective molecularly imprinted polymer sensor for indium detection based on recognition of In-Alizarin complexes. Electroanalysis 2015, 27, 1758-1765. [CrossRef]

91. Song, M.; Xu, J. Preparation of polyethylenimine-functionalized graphene oxide composite and its application in electrochemical ammonia sensors. Electroanalysis 2013, 25, 523-530. [CrossRef]

92. Hong, L.; Li, Y.; Yang, M. Fabrication and ammonia gas sensing of palladium/PPy nanocomposite. Sens. Actuators B Chem. 2010, 145, 25-31. [CrossRef]

93. Zhang, D.; Jian, C.; Sun, Y. Room-temperature high-performance ammonia gas sensor based on layer-by-layer self-assembled molybdenum disulfide/zinc oxide nanocomposite film. J. Alloys Compd. 2017, 698, 476-483. [CrossRef]

94. Ahmad, Z.; Choudhary, M.A.; Mehmood, A.; Wakeeh, R.; Akhtar, T.; Rafiq, M.A. Synthesis of PPy nano/microspheres using cobalt(III) as an oxidizing agent and its ammonia sensing behavior. Macromol. Res. 2016, 24, 596-601. [CrossRef]

95. Xu, Y.; Sui, X.; Guan, S.; Zhai, J.; Gao, L. Olfactory sensory neuron-mimetic $\mathrm{CO}_{2}$ activated nanofluidic diode with fast response rate. Adv. Mater. 2015, 27, 1851-1855. [CrossRef] [PubMed]

96. Zhang, Y.; Lim, L.-T. Colorimetric array indicator for $\mathrm{NH}_{3}$ and $\mathrm{CO}_{2}$ detection. Sens. Actuators B Chem. 2018, 255, 3216-3226. [CrossRef]

97. Li, Y.; Yang, M.J.; She, Y. Humidity sensors using in situ synthesized sodium polystyrenesulfonate/ZnO nanocomposites. Talanta 2004, 62, 707-712. [CrossRef] [PubMed]

98. Suri, K.; Annapoorni, S.; Sarkar, A.K.; Tandon, R.P. Gas and humidity sensors based on iron oxide-PPy nanocomposites. Sens. Actuators B Chem. 2002, 81, 277-282. [CrossRef]

99. Najjar, R.; Nematdoust, S. A resistive-type humidity sensor based on PPy and ZnO nanoparticles: Hybrid polymers vis-a-vis nanocomposites. RSC Adv. 2016, 6, 112129-112139. [CrossRef]

100. Su, P.G.; Huang, L.N. Humidity sensors based on $\mathrm{TiO}_{2}$ nanoparticles/PPy composite thin films. Sens. Actuators B Chem. 2007, 123, 501-507. [CrossRef]

101. Hosono, K.; Matsubara, I.; Murayama, N.; Woosuck, S.; Izu, N. Synthesis of PPy/MoO $\mathrm{M}_{3}$ hybrid thin films and their volatile organic compound gas-sensing properties. Chem. Mater. 2005, 17, 349-354. [CrossRef]

102. Savage, N.O. Gas sensing composites of metal oxides with vapor-deposited PPy. Sens. Actuators B Chem. 2009, 143, 6-11. [CrossRef]

103. Kwan, P.H.; MacLachlan, M.J.; Swager, T.M. Rotaxaned conjugated sensory polymers. J. Am. Chem. Soc. 2004, 126, 8638-8639. [CrossRef] [PubMed]

104. Lee, H.; Jung, S.H.; Han, W.S.; Moon, J.H.; Kang, S.; Lee, J.Y.; Shinkai, S. A chromo-fluorogenic tetrazole-based $\mathrm{CoBr}_{2}$ coordination polymer gel as a highly sensitive and selective chemosensor for volatile gases containing chloride. Chem. Eur. J. 2011, 17, 2823-2827. [CrossRef] [PubMed]

105. Patil, J.; Duragkar, N.; Rao, V.R. An ultra-sensitive piezoresistive polymer nano-composite microcantilever sensor electronic nose platform for explosive vapor detection. Sens. Actuators B Chem. 2014, 192, 444-451. [CrossRef]

106. Calvo-Gredilla, P.; García-Calvo, J.; Cuevas, J.; Torroba, T.; Pablos, J.-L.; García, F.; García, J.M.; Fernández-Lázaro, F. Solvent-free off-on detection of the improvised explosive triacetone triperoxide (TATP) with fluorogenic materials. Chem. Eur. J. 2017, 23, 1-8. [CrossRef] [PubMed]

107. Pangeni, D.; Nesterov, E.E. “Higher energy gap” control in fluorescent conjugated polymers: Turn-on amplified detection of organophosphorous agents. Macromolecules 2013, 46, 7266-7273. [CrossRef] 
108. Yang, Z.; Sheng, Q.; Zhang, S.; Zheng, X.; Zheng, J. One-pot synthesis of $\mathrm{Fe}_{3} \mathrm{O}_{4}$ / polypyrrole/graphene oxide nanocomposites for electrochemical sensing of hydrazine. Microchimica Acta 2017, 184, 2219-2226. [CrossRef]

109. Roales, J.; Moscoso, F.G.; Gámez, F.; Lopes-Costa, T.; Sousaraei, A.; Casado, S.; Castro-Smirnov, J.R.; Cabanillas-Gonzalez, J.; Almeida, J.; Queirós, C.; Cunha-Silva, L.; Silva, A.M.G.; Pedrosa, J.M. Preparation of luminescent metal-organic framework films by soft-imprinting for 2,4-dinitrotoluene sensing. Materials 2017, 10, 992. [CrossRef] [PubMed]

110. Wang, E.; Sun, D.; Li, H.; Sun, X.; Liu, J.; Ren, Z.; Yan, S. High efficiency organosilicon-containing polymer sensors for the detection of trinitrotoluene and dinitrotoluene. J. Mater. Chem. C 2016, 4, 6756-6760. [CrossRef]

111. Tokranova, N.A.; Novak, S.W.; Castracane, J.; Levitsky, I.A. Deep infiltration of emissive polymers into mesoporous silicon microcavities: Nanoscale confinement and advanced vapor sensing. J. Phys. Chem. C 2013, 117, 22667-22676. [CrossRef]

112. Zhang, H.; Feng, L.; Liu, B.; Tong, C.; Lü, C. Conjugation of PPV functionalized mesoporous silica nanoparticles with graphene oxide for facile and sensitive fluorescence detection of TNT in water through FRET. Dyes Pigm. 2014, 101, 122-129. [CrossRef]

113. Hussein, L.A.; El-Kosasy, A.M.; Trabik, Y.A. Comparative study of normal, micro- and nano-sized iron oxide effect in potentiometric determination of fluconazole in biological fluids. RSC Adv. 2015, 5, 37957-37963. [CrossRef]

114. Yu, G.; Qiang, L. Preparation and characterization of PTFE coating in new polymer quartz piezoelectric crystal sensor for testing liquor products. Chin. Phys. B 2015, 24, 078106. [CrossRef]

115. Liu, Y.; Zhu, L.; Luo, Z.; Tang, H. Fabrication of molecular imprinted polymer sensor for chlortetracycline based on controlled electrochemical reduction of graphene oxide. Sens. Actuators B Chem. 2013, 185, 438-444. [CrossRef]

116. Li, J.; Jiang, F.; Li, Y.; Chen, Z. Fabrication of an oxytetracycline molecular-imprinted sensor based on the competition reaction via a GOD-enzymatic amplifier. Biosens. Bioelectron 2011, 26, 2097-2101. [CrossRef] [PubMed]

117. Wang, L.-Q.; Lin, F.-Y.; Yu, L.-P. A molecularly imprinted photonic polymer sensor with high selectivity for tetracyclines analysis in food. Analyst 2012, 137, 3502-3509. [CrossRef] [PubMed]

118. Prasad, B.; Mahavir, P.; Rashmi, M.; Sharma, P. Enantioselective quantitative separation of D- and L-thyroxine by molecularly imprinted micro-solid phase extraction silver fiber coupled with complementary molecularly imprinted polymer-sensor. J. Chromatogr. A 2010, 1217, 4255-4266. [CrossRef] [PubMed]

119. Prasad, B.B.; Srivastava, A.; Prasad, A.; Tiwari, M.P. Molecularly imprinted micro solid-phase extraction technique coupled with complementary molecularly imprinted polymer-sensor for ultra-trace analysis of epinephrine in real samples. Colloids Surf. B 2014, 113, 69-76. [CrossRef] [PubMed]

120. Jiang, K.; Wang, Y.; Thakur, G.; Kotsuchibashi, Y.; Naicker, S.; Narain, R.; Thundat, T. Rapid and highly sensitive detection of dopamine using conjugated oxaborole-based polymer and glycopolymer systems. ACS Appl. Mater. Interfaces 2017, 9, 15225-15231. [CrossRef] [PubMed]

121. Pablos, J.L.; Vallejos, S.; Ibeas, S.; Muñoz, A.; Serna, F.; García, F.C.; García, J.M. Acrylic polymers with pendant phenylboronic acid moieties as "turn-off" and "turn-on" fluorescence solid sensors for detection of dopamine, glucose and, fructose in water. ACS Macro Letters 2015, 4, 979-983. [CrossRef]

122. Oh, S.; Uh, K.; Jeon, S.; Kim, J.M. A free-standing self-assembled tubular conjugated polymer sensor. Macromolecules 2016, 49, 5841-5848. [CrossRef]

123. Shirsat, M.D.; Too, C.O.; Wallace, G.G. Amperometric glucose biosensor on layer by layer assembled carbon nanotube and PPy multilayer film. Electroanalysis 2008, 20, 150-156. [CrossRef]

124. Barone, P.W.; Yoon, H.; Ortiz-García, R.; Zhang, J.; Ahan, J.H.; Kim, J.H.; Strano, M.S. Modulation of single-walled carbon nanotube photoluminescence by hydrogel swelling. ACS Nano 2009, 3, 3869-3877. [CrossRef] [PubMed]

125. Wang, Z.; Xia, J.; Qiang, X.; Xia, Y.; Shi, G.; Zhang, F.; Tang, J. Polymer-assisted in situ growth of copper nanoparticles on graphene surface for non-enzymatic electrochemical sensing of glucose. Int. J. Electrochem. Sci. 2013, 8, 6941-6950.

126. Ivanov, A.; Thammakhet, C.; Kuzimenkova, M.; Thavarungkul, P.; Kanatharana, P.; Mikhalovska, L.; Mattiasson, B. Thin semitransparent gels containing phenylboronic acid: Porosity, optical response and permeability for sugars. J. Mol. Recognit. 2008, 21, 89-95. [CrossRef] [PubMed] 
127. Hajizadeh, S.; Ivanov, A.E.; Jahanshahi, M.; Sanati, M.H.; Zhuravleva, N.V.; Mikhalovska, L.I.; Galaev, I.Y. Glucose sensors with increased sensitivity based on composite gels containing immobilized boronic acid. React. Funct. Polym. 2008, 68, 1625-1635. [CrossRef]

128. Thammakhet, C.; Thavarungkul, P.; Kanatharana, P. Development of an on-column affinity smart polymer gel glucose. Anal. Chim. Acta 2011, 695, 105-112. [CrossRef] [PubMed]

129. Ouiganon, S.; Thammakhet, C.; Thavarungkul, P. An application of optical coherence tomography and a smart polymer gel to construct enzyme-free sugar sensor. Appl. Phys. B: Lasers Opt. 2016, 122, 1-8. [CrossRef]

130. Dabrowski, M.; Sharma, P.S.; Iskierko, Z.; Noworyta, K.; Cieplak, M.; Lisowski, W.; Kutner, W. Early diagnosis of fungal infections using piezomicrogravimetric and electric chemosensors based on polymers molecularly imprinted with D-arabitol. Biosens. Bioelectron 2016, 79, 627-635. [CrossRef] [PubMed]

131. Prasad, B.; Srivastava, A.; Pandey, I.; Tiwari, M. Electrochemically grown imprinted polybenzidine nanofilm on multiwalled carbon nanotubes anchored pencil graphite fibers for enantioselective micro-solid phase extraction coupled with ultratrace sensing of D- and L-methionine. J. Chromatogr. B 2013, 912, 65-74. [CrossRef] [PubMed]

132. Iskierko, Z.; Checinska, A.; Sharma, P.S.; Golebiewska, K.; Noworyta, K.; Borowicz, P.; Kutner, W. Molecularly imprinted polymer based extended-gate field-effect transistor chemosensors for phenylalanine enantioselective sensing. J. Mater. Chem. C 2017, 5, 969-977. [CrossRef]

133. Hou, J.; Song, F.; Wang, L.; Wei, G.; Cheng, Y.; Zhu, C. In situ generated 1:1 Zn(II)-containing polymer complex sensor for highly enantioselective recognition of $N$-Boc-protected alanine. Macromolecules 2012, 45, 7835-7842. [CrossRef]

134. Wei, G.; Zhan, S.; Dai, C.; Quan, Y.; Cheng, Y.; Zhu, C. A new chiral binapthalene-based fluorescence polymer sensor for the highly enantioselective recognition of phenylalaninol. Chem. Eur. J. 2013, 19, 16066-16071. [CrossRef] [PubMed]

135. Zhang, W.; Wei, G.; Wang, Z.; Ma, J.; Zhu, C.; Cheng, Y. Highly enantioselective recognition of alaninol via the chiral BINAM-based fluorescence polymer sensor. Polymer 2016, 101, 93-97. [CrossRef]

136. Song, F.; Weir, G.; Wang, L.; Jiao, J.; Chen, Y.; Zhu, C. Salen-based chiral fluorescence polymer sensor for enantioselective recognition of $\alpha$-hydroxyl carboxylic acids. J. Org. Chem. 2012, 77, 4759-4764. [CrossRef] [PubMed]

137. Prasad, B.B.; Pandey, I. Molecularly imprinted polymer-based piezoelectric sensor for enantio-selective analysis of malic acid isomers. Sens. Actuators B Chem. 2013, 181, 596-604. [CrossRef]

138. Yadav, S.; Kumar, A.; Pundir, C.S. Amperometric creatinine biosensor based on covalently coimmobilized enzymes onto carboxylated multiwalled carbon nanotubes/polyaniline composite film. Anal. Biochem. 2011, 419, 277-283. [CrossRef] [PubMed]

139. Chow, C.F. Supramolecular polymeric chemosensor for biomedical applications: Design and synthesis of a luminescent zinc metallopolymer as a chemosensor for adenine detection. J. Fluoresc. 2012, 22, 1539-1546. [CrossRef] [PubMed]

140. Wang, X.; Li, Y.; Ding, B. Electrospun nanofiber-based sensors. In Electrospun Nanofibers for Energy and Environmental Applications, 1st ed.; Ding, B., Yu, J., Eds.; Springer: Berlin, Germany, 2014; pp. 267-297, ISBN 978-3-642-54160-5.

141. Ye, L.; Mosbach, L. Molecular imprinting: Synthetic materials as substitutes for biological antibodies and receptors. Chem. Mater. 2008, 20, 859-868. [CrossRef]

142. Creran, B.; Bunz, U.; Rotello, V. Polymer-nanoparticle assemblies for array based sensing. Curr. Org. Chem. 2015, 109, 1054-1062. [CrossRef] [PubMed]

143. Arshak, K.; Moore, E.; Lyons, G.; Harris, J.; Clifford, S. A review of gas sensors employed in electronic nose applications. Sens. Rev. 2004, 24, 181-198. [CrossRef]

144. Rodríguez-Méndez, M.-L.; De Saja, J.A.; González-Antón, R.; García-Hernández, C.; Medina-Plaza, C.; García-Cabezón, C.; Martín-Pedrosa, F. Electronic noses and tongues in wine industry. Front. Bioeng. Biotechnol. 2016, 4, 81-87. [CrossRef] [PubMed]

145. Nanto, H.; Douguchi, Y.; Yokoi, Y. Smart electronic nose using polymer-film coated quartz resonator gas sensor for identification of harmful gases. Proc. Soc. Photo Opt. Instrum. Eng. 1999, 3856, 317-327. [CrossRef]

146. Sartore, L.; Barbaglio, M.; Borgese, L.; Bontempi, E. Polymer-grafted QCM chemical sensor and application to heavy metal ions real time detection. Sens. Actuators B Chem. 2011, 155, 538-544. [CrossRef] [PubMed] 
147. Cao, Z.; Guo, J.; Fan, X.; Xu, J.; Fan, Z.; Du, B. Detection of heavy metal ions in aqueous solution by Poly(MBTVBC-co-VIM)-coated QCM sensor. Sens. Actuators B 2017, 157, 34-41. [CrossRef]

148. Fan, Y.-Q.; Gao, F.; Wang, M.; Zhuang, J.; Tang, G.; Zhang, Y.-J. Recent development of wearable microfluidics applied in body fluid testing and drug delivery. Chin. J. Anal. Chem. 2017, 45, 455-463. [CrossRef]

149. Qi, J.; Li, B.; Wang, X.; Zhang, Z.; Wang, Z.; Han, J.; Chen, L. Three-dimensional paper-based microfluidic chip device for multiplexed fluorescence detection of $\mathrm{Cu}^{2+}$ and $\mathrm{Hg}^{2+}$ ions based on ion imprinting technology. Sens. Actuators B Chem. 2017, 251, 224-233. [CrossRef]

150. Kudr, J.; Ondrej, Z.; Klimanek, M.; Vrba, R.; Adam, V. Microfluidic electrochemical devices for pollution analysis-A review. Sens. Actuators B Chem. 2017, 246, 578-590. [CrossRef]

151. Naveen, M.; Gurudatt, N.; Shim, Y.-B. Applications of conducting polymer composites to electrochemical sensors: A review. Appl. Mater. Today 2017, 9, 419-433. [CrossRef]

152. Bai, H.; Wang, S.; Liu, P.; Xiong, C.; Zhang, K.; Cao, Q. Electrochemical sensor based on in situ polymerized ion-imprinted membranes at graphene modified electrode for palladium determination. J. Electroanal. Chem. 2016, 771, 29-36. [CrossRef]

153. Caliò, A.; Dardano, P.; Di Palma, V.; Bevilacqua, M.; Di Matteo, A.; Iuele, H.; De Stefano, L. Polymeric microneedles based enzymatic electrodes for electrochemical biosensing of glucose and lactic acid. Sens. Actuators B Chem. 2016, 236, 343-349. [CrossRef]

154. Liu, Y.; Meiting, W.; Yue, H.; Zhu, L.; Du, Y. An electrochemical sensor based on a molecularly imprinted polymer for determination of anticancer drug mitoxantrone. Sens. Actuators B Chem. 2018, 255, 544-551. [CrossRef]

155. Yu, C.H.; Huang, X.Y.; Lei, F.H.; Tan, X.C.; Wei, Y.C.; Li, H. Molecularly imprinted electrochemical sensor based on nickel nanoparticle-modified electrodes for phenobarbital determination. Electrochim. Acta 2014, 141, 45-50. [CrossRef]

156. Shrivastava, S.; Jadon, N.; Jain, R. Next-generation polymer nanocomposite-based electrochemical sensors and biosensors: A review. Trends Anal. Chem. 2016, 82, 55-67. [CrossRef]

157. Lv, A.; Wang, M.; Wang, Y.; Bo, Z.; Chi, L. Investigation into the sensing process of high-performance $\mathrm{H}_{2} \mathrm{~S}$ sensors based on polymer transistors. Chemistry 2016, 22, 3654-3659. [CrossRef] [PubMed]

158. Liqiang, L.; Baumgarten, M.; Müllen, K.; Nan, L.; Fuchs, H.; Lifeng, C. High performance field-effect ammonia sensors based on a structured ultrathin organic semiconductor film. Adv. Mater. 2013, 25, 3419-3425. [CrossRef]

159. Lv, A.; Pan, Y.; Chi, L. Gas sensors based on polymer field-effect transistors. Sensors 2017, 17, 213. [CrossRef] [PubMed]

160. Chuan-Guang, Q.; Cai-Xi, L.; Gao-Wei, O.; Ke, Q.; Feng, Z.; Hai-Tong, S.; Xiao-Hui, W. Progress of azobenzene-based photoswitchable molecular probes and sensory chips for chemical and biological analysis. Chin. J. Anal. Chem. 2015, 43, 433-443. [CrossRef]

161. Song, S.; Choi, H.; Hong, J.; Kim, B.; Sim, S.; Yoon, H. Selective antigen-antibody recognition on SPR sensor based on the heat-sensitive conformational change of poly( $N$-isopropylacrylamide). Colloids Surf. A Physicochem. Eng. Asp. 2008, 313, 504-508. [CrossRef]

162. Wilhelmina de Groot, G.; Demarche, S.; Santonicola, M.; Tiefenauer, L.; Vancso, G. Smart polymer brush nanostructures guide the self-assembly of pore-spanning lipid bilayers with integrated membrane proteins. Nanoscale 2014, 6, 2228-2237. [CrossRef] [PubMed]

163. Liu, S.; Sun, H.; Nagarajan, R.; Kumar, J.; Gu, Z.; Cho, J.; Kurup, P. Dynamic chemical vapor sensing with nanofibrous film based surface acoustic wave sensors. Sens. Actuators A Phys. 2011, 167, 8-13. [CrossRef]

164. Qianqian, L.; Yang, L.; Mujie, Y. Highly sensitive and ultrafast response surface acoustic wave humidity sensor based on electrospun polyaniline/poly(vinyl butyral) nanofibers. Anal. Chim. Acta 2012, 748, 73-80. [CrossRef]

165. Thiha, A.; Ibrahim, F.; Muniandy, S.; Dinshaw, I.J.; Teh, S.J.; Thong, K.L.; Leo, B.F.; Madou, M. All-carbon suspended nanowire sensors as rapid highly sensitive label-free chemiresistive biosensing platform. Biosens. Bioelectron. 2018, 107, 145-152. [CrossRef] [PubMed]

166. Scampicchio, M.; Arecchi, A.; Lawrence, N.; Mannino, S. Nylon nanofibrous membrane for mediated glucose biosensing. Sens. Actuators B Chem. 2010, 145, 394-397. [CrossRef] 
167. Manesh, K.; Santhosh, P.; Gopalan, A.; Lee, K. Electrospun poly(vinylidene fluoride)/ poly(aminophenylboronic acid) composite nanofibrous membrane as a novel glucose sensor. Anal. Biochem. 2007, 360, 189-195. [CrossRef] [PubMed]

168. Trigo-López, M.; Pablos, J.L.; Muñoz, A.; Ibeas, S.; Serna, F.; García, F.C.; García, J.M. Aromatic polyamides and acrylic polymers as solid sensory materials and smart coated fibres for high acidity colorimetric sensing. Polym. Chem. 2015, 6, 3110-3120. [CrossRef]

169. Ghosh, K.R.; Saha, S.K.; Gao, J.P.; Wang, Z.Y. Direct detection of ultralow trace amounts of isocyanates in air using a fluorescent conjugated polymer. Chem. Commun. 2014, 50, 716-718. [CrossRef] [PubMed]

170. Cho, J.; Anandakathir, R.; Kumar, A.; Kumar, J.; Kurup, P.U. Sensitive and fast recognition of explosives using fluorescent polymer sensors and pattern recognition analysis. Sens. Actuators B Chem. 2011, 160, 1237-1243. [CrossRef]

171. Dong, L.; Deng, C.; He, C.; Shi, L.; Fu, Y.; Zhu, D.; Chen, J. Highly sensitive vapor detection of amines with fluorescent conjugated polymer: A novel lasing turn-on sensory mechanism. Sens. Actuators B Chem. 2013, 180, 28-43. [CrossRef]

172. Dong, W.; Fei, T.; Scherf, U. Conjugated polymers containing tetraphenylethylene in the backbones and side-chains for highly sensitive TNT detection. RSC Adv. 2018, 8, 5760-5767. [CrossRef]

173. Trigo-López, M.; Muñoz, A.; Ibeas, S.; García, F.C.; Serna, F.; García, J.M. Solid sensory polymer kit for the easy and rapid determination of the concentration of water in organic solvents and ambient humidity. Sens. Actuators B Chem. 2014, 191, 233-238. [CrossRef]

174. Toncelli, C.; Arzhakova, O.; Dolgova, A.; Volynskii, A.; Kerry, J.; Papkovsky, D. Phosphorescent oxygen sensors produced by spotcrazing of polyphenylenesulfide films. J. Mater. Chem. C 2014, 2, 8035-8041. [CrossRef]

175. Waskitoaji, W.; Tsuyoshi, H.; Watanabe, M.; Nishide, H. Pt-porpholactone- and -porphyrin-based luminescent sensory polymer coating for visualization of oxygen pressure distribution on biplanar surface. React. Funct. Polym. 2010, 70, 669-673. [CrossRef]

176. Hyakutake, T.; Ishigami, Y.; Kato, J.; Inukai, J.; Miyatake, K.; Nishide, H.; Watanabe, M. Luminescent sensory polymer coating composed of platinumporphyrin and poly(trimethylsilylpropyne) for real-time poly(trimethylsilylpropyne) oxygen visualization in operating PEFCs. Macromol. Chem. Phys. 2011, 212, 42-47. [CrossRef]

177. Rezaei, B.; Boroujeni, M.K.; Ensafi, A.A. Fabrication of DNA, o-phenylenediamine, and gold nanoparticle bioimprinted polymer electrochemical sensor for the determination of dopamine. Biosens. Bioelectron. 2015, 66, 490-496. [CrossRef] [PubMed]

178. Jiang, H.; Wang, E.; Wang, J. Gas-breathing polymer film for constructing switchable ionic diodes. RSC Adv. 2015, 5, 35622-35630. [CrossRef]

179. Kolodziejczyk, B.; Winther-Jensen, O.; Pereira, B.; Nair, S.; Winther-Jensen, B. Patterning of conducting layers on breathable substrates using laser engraving for gas sensors. J. Appl. Polym. Sci. 2015, 132, 42359-42361. [CrossRef]

180. Huang, W.; Bender, M.; Seehafer, K.; Wacker, I.; Schröder, R.R.; Bunz, U.H.F. A tetraphenylethene-based polymer array discriminates nitroarenes. Macromolecules. 2018, 51, 1345-1350. [CrossRef]

181. Lorwongtragool, P.; Sowade, E.; Watthanawisuth, N.; Baumann, R.; Kerdcharoen, T. A novel wearable electronic nose for healthcare based on flexible printed chemical sensor array. Sensors 2014, 14, 19700-19712. [CrossRef] [PubMed]

182. Long, Z.; Lu, Y.; Zhang, M.; Qiu, H. Selective recognition and discrimination of water-soluble azo dyes by a seven-channel molecularly imprinted polymer sensor array. J. Sep. Sci. 2014, 37, 2764-2770. [CrossRef] [PubMed]

183. Benz, M.; Patel, S.V. Freestanding chemiresistive polymer composite ribbons as high-flux sensors. J. Appl. Polym. Sci. 2012, 125, 3986-3995. [CrossRef]

184. Stella, J.; Barisci, J.; Serra, G.; Wallace, G.; De Rossi, D. Characterization of olive oil by an electronic nose based on conducting polymers. Sens. Actuators B Chem. 2000, 63, 1-9. [CrossRef]

185. Hossain, M.; Aminur Rahman, G.; Freund, M.; Jayas, D.; White, N.D.; Shafai, C.; Thomson, D.J. Fabrication and optimization of a conducting polymer sensor array using stored grain model volatiles. J. Agric. Food Chem. 2012, 60, 2863-2873. [CrossRef] [PubMed] 
186. Mirmohseni, A.; Hassanzadeh, V. Application of polymer-coated quartz crystal microbalance (QCM) as a sensor for BTEX compounds vapors. J. Appl. Polym. Sci. 2001, 79, 1062-1066. [CrossRef]

187. Temel, F.; Tabakci, M. Calix[4]arene coated QCM sensors for detection of VOC emissions: Methylene chloride sensing studies. Talanta 2016, 153, 221-227. [CrossRef] [PubMed]

188. Pasupathy, P.; Trivedi, T.; Leonhardt, B.; Zhang, S.; Ekerdt, J.; Neikirk, D. Miniature passive wireless resonant platform for chemical memory-based threshold sensing. IEEE Sens. J. 2017, 17, 1209-1210. [CrossRef]

189. Seyama, M.; Sugimoto, I.; Nakamura, M. Aroma sensing and indoor air monitoring by quartz crystal resonators with sensory films prepared by sputtering of biomaterials and sintered polymers. Biosens. Bioelectron. 2004, 20, 814-824. [CrossRef] [PubMed]

190. Royal, M.; Jokerst, N.; Fair, R. Integrated sample preparation and sensing: Polymer microresonator sensors embedded in digital electrowetting microfluidic systems. IEEE Photonics J. 2012, 4, 2126-2135. [CrossRef]

191. Matsumoto, K.; Tiu, K.; Kawamura, A.; Advincula, R.; Miyata, T. QCM sensing of bisphenol A using molecularly imprinted hydrogel/conducting polymer matrix. Polymer 2016, 48, 525-532. [CrossRef]

192. Tokuyama, H.; Kitamura, E.; Seida, Y. Detection of Au(III) ions using a poly( $N, N$-dimethylacrylamide)-coated QCM sensor. Talanta 2016, 146, 507-509. [CrossRef] [PubMed]

193. Eo, S.H.; Song, S.; Yoon, B.; Kim, J.M. A microfluidic conjugated-polymer sensor chip. Adv. Mater. 2008, 20, 1690-1694. [CrossRef]

194. Funfak, A.; Hartung, R.; Cao, J.; Martin, K.; Wiesmüller, K.-H.; Wolfbeis, O.; Köhler, J. Highly resolved dose-response functions for drug-modulated bacteria cultivation obtained by fluorometric and photometric flow-through sensing in microsegmented flow. Sens. Actuators B Chem. 2009, 142, 66-72. [CrossRef]

195. Chou, J.; Du, N.; Ou, T.; Floriano, P.; Christodoulides, N.; McDevitt, J. Hot embossed polyethylene through-hole chips for bead-based microfluidic devices. Biosens. Bioelectron. 2013, 42, 653-660. [CrossRef] [PubMed]

196. Coelho, M.; Giarola, J.; Da Silva, A.; Tarley, C.; Borges, K.; Pereira, A. Development and application of electrochemical sensor based on molecularly imprinted polymer and carbon nanotubes for the determination of carvedilol. Chemosensors 2016, 4, 22. [CrossRef]

197. Zhiani, R.; Ghanei-Motlag, M.; Razavipanah, I. Selective voltammetric sensor for nanomolar detection of silver ions using carbon paste electrode modified with novel nanosized Ag(I)-imprinted polymer. J. Mol. Liq. 2016, 219, 554-560. [CrossRef]

198. Khadem, M.; Faridbod, F.; Norouzi, P.; Foroushani, A.R.; Ganjali, M.R.; Shahtaheri, S.J.; Yarahmadi, R. Modification of carbon paste electrode based on molecularly imprinted polymer for electrochemical determination of diazinon in biological and environmental samples. Electroanalysis 2017, 29, 708-715. [CrossRef]

199. Karimian, N.; Gholivand, M.; Malekzadeh, G. Cefixime detection by a novel electrochemical sensor based on glassy carbon electrode modified with surface imprinted polymer/multiwall carbon nanotubes. J. Electroanal. Chem. 2016, 771, 64-72. [CrossRef]

200. Xu, M.; Song, Y.; Ye, Y.; Gong, C.; Shen, Y.; Wang, L. A novel flexible electrochemical glucose sensor based on gold nanoparticles/polyaniline arrays/carbon cloth electrode. Sens. Actuators B Chem. 2017, 252, 1187-1193. [CrossRef]

201. Aziz, S.; Bum, K.; Yang, J.; Yang, B.-S.; Kang, C.; Doh, Y.; Kim, Y. Fabrication of $\mathrm{ZnSnO}_{3}$ based humidity sensor onto arbitrary substrates by micro-nano scale transfer printing. Sens. Actuators A Phys. 2016, 246, 1-8. [CrossRef]

202. Klink, M.; Iwuoh, E.; Ebenso, E. The electro-catalytic and redox-mediator effects of nanostructured PDMA-PSA modified-electrodes as phenol derivative sensors. Int. J. Electrochem. Sci. 2011, 6, 2429-2442.

203. Ong, P.-L.; Levitsky, I. Fluorescent gas sensors based on nanoporous optical resonators (microcavities) infiltrated with sensory emissive polymers. IEEE Sens. J. 2010, 11, 2947-2951. [CrossRef]

204. Che, Y.; Gross, D.; Huang, H.; Yang, D.; Yang, X.; Discekici, E.; Zang, L. Diffusion-controlled detection of trinitrotoluene: Interior nanoporous structure and low highest occupied molecular orbital level of building blocks enhance selectivity and sensitivity. J. Am. Chem. Soc. 2012, 134, 4978-4982. [CrossRef] [PubMed]

205. Li, M.; Liu, H.; Ren, X. Ratiometric fluorescence and mesoporous structured imprinting nanoparticles for rapid and sensitive detection 2,4,6-trinitrophenol. Biosens. Bioelectron. 2017, 89, 899-905. [CrossRef] [PubMed] 
206. Liu, H.; Liu, H. Selective dye adsorption and metal ion detection using multifunctional silsesquioxane-based tetraphenylethene-linked nanoporous polymers. J. Mater. Chem. A 2017, 5, 9156-9162. [CrossRef]

207. Stofik, M.; Semerádtová, A.; Malý, J.; Kolska, Z.; Nedela, Z.; Wrobel, D.; Slepicka, P. Direct immobilization of biotin on the micro-patterned PEN foil treated by excimer laser. Colloids Surf. B 2015, 128, 363-369. [CrossRef] [PubMed]

208. Semerádtová, A.; Stofik, M.; Nedela, O.; Stanek, O.; Slepicka, P.; Kolska, Z.; Malý, J. A simple approach for fabrication of optical affinity-based bioanalytical microsystem on polymeric PEN foils. Colloids Surf. B 2018, 165, 28-36. [CrossRef] [PubMed]

(C) 2018 by the authors. Licensee MDPI, Basel, Switzerland. This article is an open access article distributed under the terms and conditions of the Creative Commons Attribution (CC BY) license (http:/ / creativecommons.org/licenses/by/4.0/). 